\title{
PENDAMPINGAN MASYARAKAT PESISIR DESA MULADIMENG DALAM PENANAMAN POHON MANGROVE SEBAGAI BENTUK KEPEDULIAN LINGKUNGAN SERTA UPAYA MENUNJANG EKONOMI MASYARAKAT
}

\author{
Nurasia $^{1^{*}}$ \\ Ahyar Aminuddin ${ }^{2}$ \\ Nurul Hidayanti ${ }^{3}$ \\ 1,2,3 Universitas Cokroaminoto Palopo, Palopo, Indonesia \\ nurasia.kimia99@gmail.com $^{\left.1^{*}\right)}$ \\ nurulhidayanti640@gmail.com $^{3)}$
}

Kata Kunci:

[Konservasi, Mangrove]

\begin{abstract}
Ekosistem mangrove merupakan ekosistem interface antara ekosistem daratan dengan ekosistem lautan. Oleh karena itu, ekosistem ini mempunyai fungsi spesifik yang keberkelangsungannya bergantung pada dinamika yang terjadi di ekosistem daratan dan lautan. Keberadan hutan mangrove sangat menentukan dan menunjang tingkat perkembangan sosial dan perekonomian masyarakat pesisir pantai, di Desa Muladimeng yang merupakan daerah pesisir pantai tentunya ekosistem mangrove sangat berpengaruh bagi kegiatan yang ada di sana karena selain sektor pertanian sektor perikanan dan kelautan di desa Muladimeng merupakan sumber penghasilan terbesar bagi masyarakat, maka dari itu kegiatan ini dilakukan sebagai upaya untuk memberikan edukasi serta melakukan konservasi diwilayah yang mengalami tingkat kerusakan mangrove yang tergolong parah. Persepsi dan sikap masyarakat terhadap konservasi mangrove sangat menentukan keberhasilan kegiatan konservasi mangrove. Kegiatan ini bertujuan untuk memberikan edukasi kepada masyarakat tentang pentingnya ekosistem mangrove bagi daerah pesisir.
\end{abstract}

\section{Pendahuluan}

Mangrove adalah berbagai jenis vegetasi dari tingkat sedang hingga tinggi dan semaksemak yang tumbuh di sepanjang daerah pasang surut atau daerah muara sungai di daerah tropis dan sub-tropis antara garis lintang $30^{\circ} \mathrm{N}$ dan $30^{\circ} \mathrm{S}$ (Giri et al., 2011). Ekosistem mangrove merupakan salah satu tipe ekosistem yang banyak dimanfaatkan masyarakat pesisir dalam menunjang kehidupannya, baik secara langsung (tangible) maupun tidak langsung (intangible). Hutan mangrove telah terbukti dapat memberikan berbagai manfaat ekonomi dan cadangan makanan bagi masyarakat lokal (Uddin et al., 2013).

Ekosistem mangrove merupakan sumberdaya alam yang memberikan banyak keuntungan bagi manusia, berjasa untuk produktivitasnya yang tinggi serta kemampuannya memelihara alam. Mangrove banyak memberikan fungsi ekologis dan karena itulah mangrove menjadi salah satu penunjang utama keberhasilan perikanan 
baik perikanan laut maupun budidaya. Mangrove memproduksi nutrien yang dapat menyuburkan perairan laut dan tambak, mangrove membantu dalam perputaran karbon, nitrogen dan sulfur, serta perairan mengrove kaya akan nutrien baik nutrien organik maupun anorganik. Dengan rata-rata produksi primer yang tinggi mangrove dapat menjaga keberlangsungan populasi ikan, kerang dan lainnya. Tanaman mangrove mempunyai habitus yang khas dibandingkan tanaman lainnya. Struktur vegetasi sebagian besar tanaman mangrove, terutama yang hidup di lumpur dan perairan, memperlihatkan ciri khas tanaman peralihan darat dan laut seperti bentuk perakaran dengan akar gantung, akar nafas, dan akar tunggang yang kuat menancap ke dalam lumpur perairan. Selain mampu menahan masuknya air laut ke daratan, perakaran mangrove juga mampu menyerap logam berat dalam jumlah besar sehingga mampu menjadi biofilter bagi lingkungan (Heriyanto \& Subiandono, 2011). Bentuk akar yang khas serta tingginya material organik yang merupakan jatuhan daun mangrove menjadikan ekosistem mangrove kaya akan material organik dan tempat berbagai jenis ikan, udang, dan fauna payau lain untuk mencari makan (feeding ground), bertelur dan memijah (spawning ground), serta berkembang biak dan membesarkan (nursery ground). Kayanya wilayah perairan mangrove menjadikan tempat hidup ideal bagi berbagai jenis fauna lainnya, seperti reptile, burung, orang utan, badak, dan binatang buas lainnya. Fungsi ekologis lainnya dari keberadaan mangrove di pesisir sebagai buffer zone kawasan daratan untuk menyaring limbah, mencegah abrasi dan angin kencang, serta masuknya air laut ke daratan, perlu ditingkatkan kepada masyarakat.

Hutan mangrove merupakan sumber berbagai produksi hasil hutan yang bernilai ekonomi, seperti kayu, sumber pangan, bahan kosmetika, bahan pewarna dan penyamak kulit serta sumber pakan. Di samping itu juga mendukung peningkatan hasil tangkapan ikan dan budidaya tambak yang diusahakan para nelayan dan petani tambak. Fungsi hutan mangrove di wilayah pesisir bukan hanya penting sebagai pelindung fisik, tetapi juga sebagai bagian terintegrasi dari eksositem wilayah pesisir lainnya, seperti ekosistem terumbu karang dan ekosistem padang lamun (Pontoh, 2011). Keberadaan hutan mangrove dapat memberikan berbagai manfaat, di antaranya ialah sebagai stabilitator kondisi pantai, mencegah terjadinya abrasi dan intrusi air laut, sebagai sumber keanekaragaman biota akuatik dan non-akuatik, sebagai sumber bahan yang dapat dikonsumsi masyarakat dan lain sebagainya (Yuliasamaya et al., 2014). Bagi masyarakat pesisir, ekosistem mangrove berperan penting dalam menopang kehidupan mereka, baik dari aspek ekonomi maupun ekologi. Pada aspek ekonomi, mangrove digunakan untuk arang, kayu bakar, alat tangkap ikan tradisional (paropo), dan tempat penangkapan jenis ikan, udang dan kepiting, sedangkan dari segi ekologis, ekosistem mangrove berfungsi sebagai penghasil bahan pelapukan (decomposer) yang merupakan sumber makanan penting untuk invertebrata kecil pemakan bahan pelapukan (detritus). Selanjutnya, mangrove juga berperan sebagai makanan bagi hewan yang lebih besar. Ekosistem mangrove juga merupakan daerah asuhan (nursery ground) bagi ikan dan kerangkerangan (Hussain and Badola, 2010).

Dalam beberapa tahun terakhir, keberadaan hutan mangrove yang banyak memberikan manfaat itu telah banyak mengalami kerusakan yang sangat memprihatinkan, Kusmana (2003) menyebutkan bahwa ada tiga faktor utama penyebab kerusakan mangrove, yaitu (1) pencemaran, (2) konversi hutan mangrove yang kurang memperhatikan faktor lingkungan dan (3) penebangan yang berlebihan. Hampir diseluruh wilayah Indonesia saat ini mengalami kerusakaan mangrove, tidak terkecuali hutan mangrove yang ada di Desa Muladimeng. 
Desa Muladimeng merupakan salah satu desa yang terdapat didalam wilayah Kecamatan Ponrang Kabupaten Luwu Provinsi Sulawesi Selatan. Berbagai upaya konservasi ekosistem mangrove di Desa Muladimeng terus dilakukan oleh pemerintah maupun lembaga non pemerintah. Beberapa diantaranya adalah melakukan kegiatan rehabilitasi kawasan tambak yang telah rusak. Namun seringkali upaya konservasi tersebut mengalami kendala karena ketidaksamaan persepsi dan sikap masyarakat terhadap upaya konservasi mangrove tersebut. Untuk mencegah terjadinya kegagalan yang sama, maka persepsi masyarakat terhadap konservasi ekosistem mangrove di Desa Muladimeng menjadi suatu hal yang perlu diketahui, sebab persepsi merupakan suatu dasar dari pembentukan sikap atau perilaku. Kepedulian terhadap lingkungan sekitar tentu saja harus menjadi usaha dari seluruh lapisan masyarakat, termasuk kalangan akademisi. Sebagai generasi penerus bangsa yang akan mewarisi lingkungan, maka dari itu kalangan akademis diangap perlu diperkenalkan pada usaha melestarikan lingkungan sekitar. Pengenalan mereka terhadap lingkungan dan pelestariannya dapat dimulai dari usaha untuk memperbaiki kerusakan lingkungan itu sendiri.

Salah satu upaya yang dilakukan oleh civitas akademika Universitas Cokroaminoto Palopo adalah memberikan edukasi terhadap pentinganya tumbuhan mangrove terhadap keberlangsungan kehidupan di daerah pesisir pantai. Kegiatan ini dirangkaiakan dengan kegiatan penanaman pohon mangrove guna penyelamatan lingkungan pesisir di desa Muladimeng. Kegiatan ini juga sebagai salah satu upaya dalam meningkatkan perekonomian masyarakat mengingat masyarakat desa Muladimeng memilliki ketergantungan di bidang kelautan dan perikanan. Kegiatan ini selain untuk mengenalkan dan memberikan pelatihan pada mahasiswa, dosen dan masyarakat setempat dalam berkontribusi secara langsung dalam menjaga lingkungan, juga ingin memberikan kontribusi pada masyarakat umum melalui kegiatan penanaman pohon mangrove.

\section{Metode Pelaksanaan}

Persiapan pelaksanaan kegiatan diawali dengan survey dan observasi untuk memilih lokasi yang akan ditempati melaksanakan kegiatan penanaman mangrove. Setelah konsolidasi dengan pejabat setempat untuk mengurus perijinan agar kegiatan mendapat dukungan dari masyarakat setempat, tahap persiapan dilanjutkan dengan persiapan alat dan bibit pohon magrove, serta penyusunan urutan kegiatan. Pelaksanaan kegiatan penanaman ini bertempat di Desa Muladimeng, Kecamatan Ponrang, Kabupaten Luwu, pada tanggal 13 Maret 2021. Jumlah peserta yang mengikuti kegiatan ini kurang lebih 30 orang yang terdiri dari dosen, aparat desa setempat, pihak Danramil, pihak Kecamatan Ponrang, Pihak kepolisian setempat, serta masyarakat desa Muladimeng, dan juga mahasiswa KKN Tematik Universitas Cokroaminoto Palopo dengan tetap menerapkan protokol kesehatan, Metode kegiatan yang digunakan pada kegiatan pengabdian kepada masyarakat ini adalah dengan penyuluhan dan praktik langsung.

\section{Hasil dan Pembahasan}

Berdasarkan hasil observasi yang telah dilakukan mangrove di Pantai Desa Muladimeng tumbuh pada daerah intertidal yaitu daerah pantai yang dipengaruhi pasang surut, kemudian dari hasil observasi pula ditemukan bahwa di desa muladimeng juga 
memiliki sebaran habitat mangrove yang tingkat kerusakan berbeda-beda, salah satunya di dusun lowa pantai dimana tingkat kerusakan yang terjadi disana sudah parah dimana kerusakan tersebut disebabkan oleh beberapa faktor diantaranya faktor dari masyarakat itu sendiri dimana masyarakat disana menebang pohon mangrove untuk dimanfaatkan untuk hal-hal seberti untuk kayu bakar, membangun rumah-rumah dan lain-lain, kemudian faktor dari alam yaitu tingkat gelombang di daerah tersebut terbilang kencang. Maka atas dasar tersebut diatas maka civitas akademika Universitas Cokroaminoto Palopo yang terdiri dari dosen dan mahasiswa KKN-Tematik UNCP berinisiatif untuk melaksanakan kegiatan konservasi di sekitaran pesisir pantai yang memiliki tingkat kerusakan yang terbilang cukup tinggi. Penanaman pohon mangrove adalah salah satu usaha yang dapat dilakukan untuk mengurangi potensi abrasi pada daerah pesisir pantai. Dengan semakin tingginya kesadaran akan pentingnya hutan mangrove maka akan semakin tinggi tingkat pelestarian alam yang bisa dilakukan. Apabila seluruh lapisan masyarakat mempunyai komitmen yang tinggi dalam pelestarian pantai dan alamnya, maka akan semakin mudah kerjasama yang dapat dilakukan untuk memperbaiki daerah pesisir yang terdampak abrasi dan membantu perekonomian masyarakat sekitarnya. Maka dari itu kami melakukan kegiatan ini dengan melibatkan pihak masyarakat serta mahasiswa untuk meningkatkan kesadaran masyarakat serta mahasiswa tentang pentingnya ekosistem mangrove.

Kegiatan ini diawali dengan melakukan rapat dengan masyarakat serta aparat desa setempat untuk menjalankan kegiatan ini. Selanjutnya setelah ditentukan lokasi serta mekanisme kegiatan yang akan dijalankan selanjutnya kami melaksanakan beberapa kegiatan, yaitu

\section{a. Persiapan}

Untuk melaksanakan kegiatan ini mahasiswa terlebih dahulu melakukan observasi serta persiapan alat untuk melaksanakan kegiatan. Observasi dilakukan di pesisir pantai Desa Muladimeng, dimana kami mendapatkan lokasi yang tingkat kerusakannya cukum tinggi. Selanjtnya, mahasiswa berkonsultasi dengan dosen terkait teknis pelaksanaan kegiatan. Selanjutnya adalah mahasiswa menyiapkan bibit pohon mangrove, bibit mangrove yang kami gunakan dalam kegiatan ini merupakan bibit mangrove yang sudah jatuh ketanah yang kami ambil kemudian kami diamkan kurang lebih 10 hari untuk menumbuhkan akar pada bibit mangrove dan ada juga bibit mangrove yang kami ambil kemudian langsung ditanam juga, kemudian persiapan selanjutnya yaitu pengambilan patok bambu yang akan digunakan untuk menopang bibit pohon mangrove yang akan ditanam (Lihat Gambar 1)
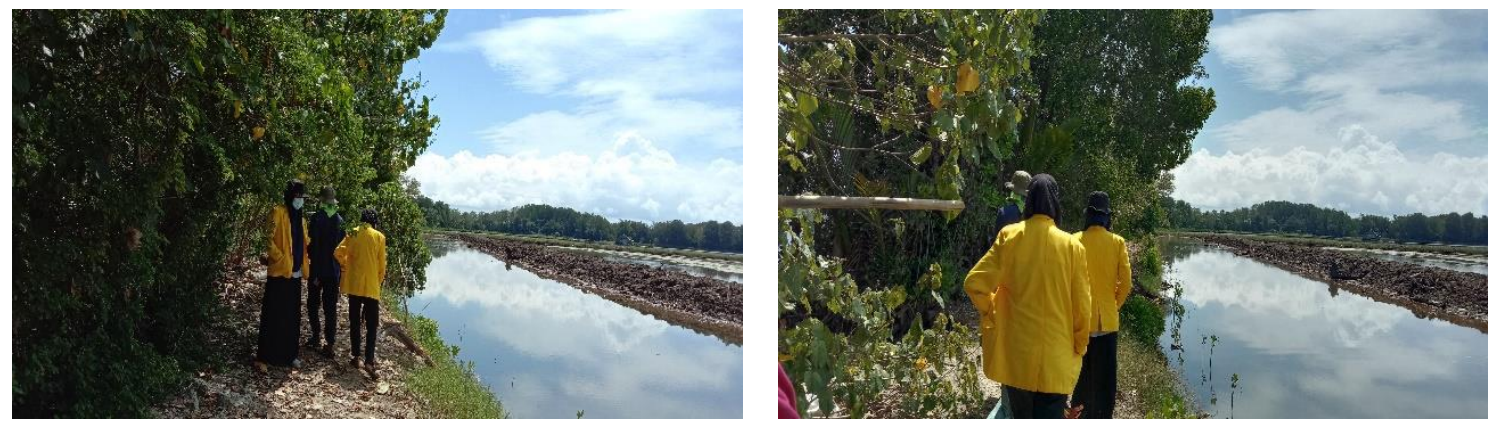


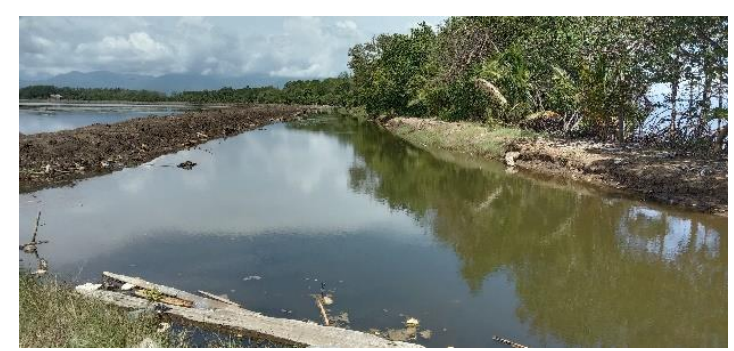

Gambar 1. Observasi kawasan yang akan dijadikan lokasi penanaman

b. Pendampingan Penanaman

Pada pelaksanaan kegiatan penanaman mangrove ini melibatkan beberapa pihak diantaranya Mahasiswa KKN Tematik UNiversitas Cokroaminoto Palopo, aparat Desa Muladimeng, Danramil, Kapolsek Ponrang, pihak dari Kecamatan Ponrang, serta masyarakat setempat (Lihat Gambar 2).

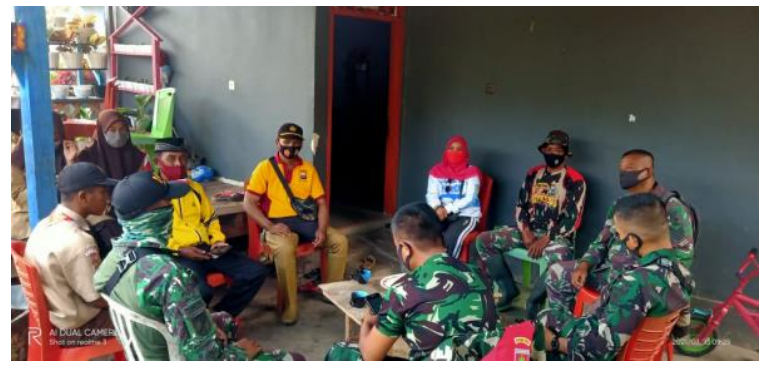

Gambar 2. Arahan dari kepala desa Muladimeng

Pada pelaksanaan kegiatan penanaman mangrove diawali dengan bapak kepala desa Muladimeng, memberikan arahan tentang pelaksanaan kegiatan kemudian dilanjutkan dengan memberikan arahan tentang bagaimana cara penanaman mangrove yang baik, mulai dari jarak tanam sampai dengan cara mengikat bibit mangrove ke patok yang sudah disiapkan, sehingga hasil penanaman akan bagus dan tumbuh dengan baik (Lihat Gambar 3).
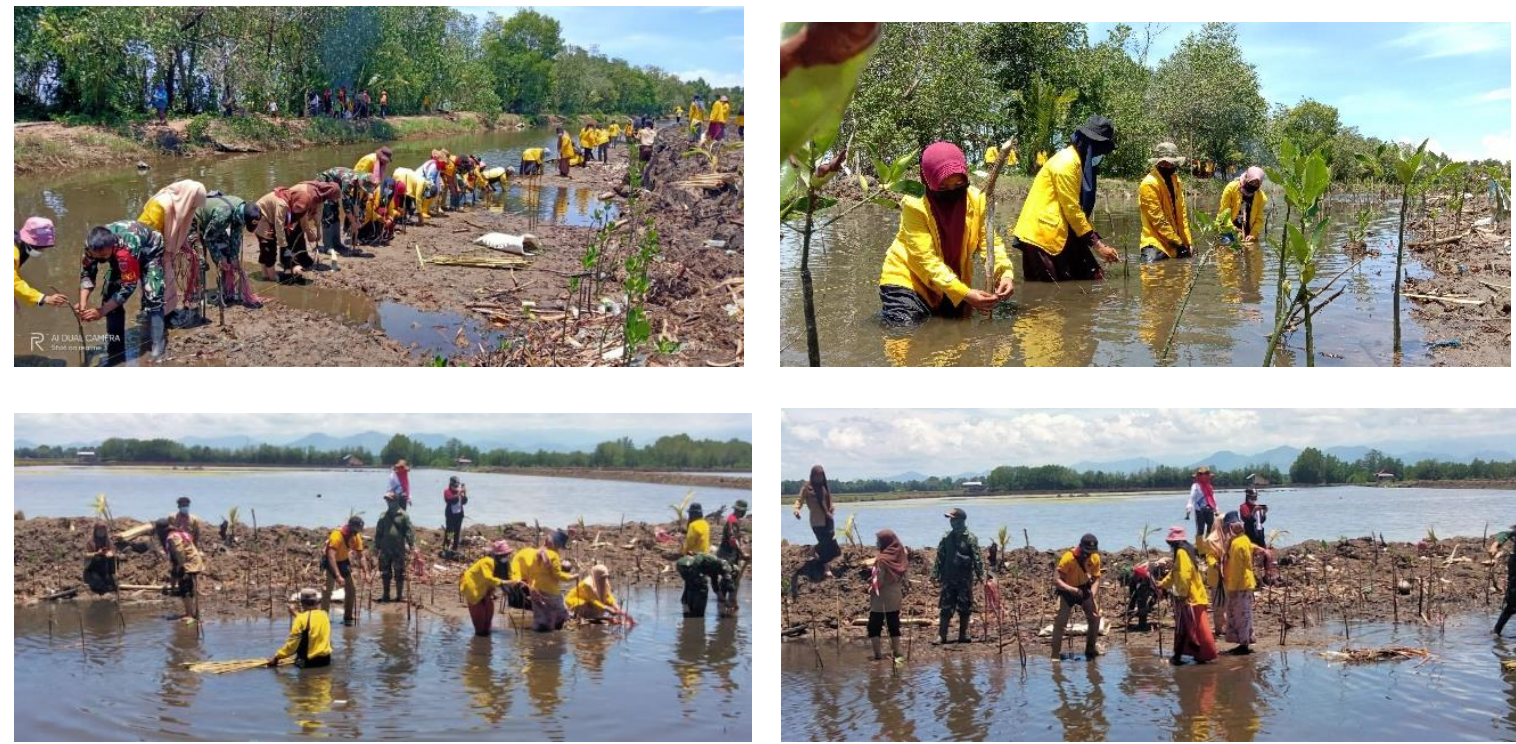


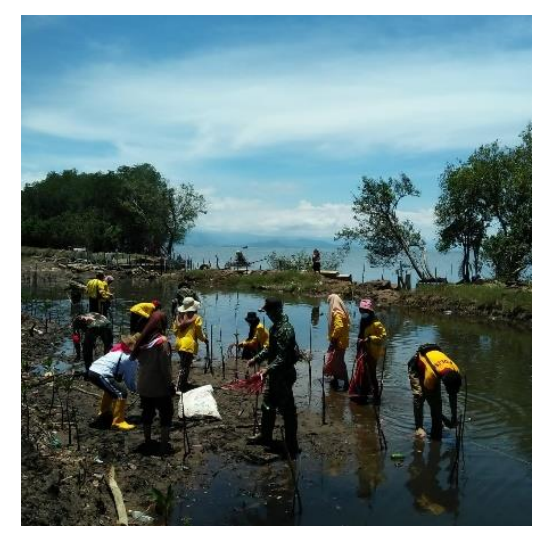

Gambar 3. Pelaksanaan kegiatan penanaman mangrove

Pada kegiatan ini kami melibatkan masyarakat setempat guna untuk memberikan informasi serta edukasi kepada masyarakat tentang pentingnya ekosistem mangrove guna menopang tingkat perekonomian mengingat banyaknya masyarakat yang perekonomiannya ditopang dari sektor kelautan dan perikanan. Setelah kegiatan ini diharapkan tingkat kepedulian serta pengetahuan masyarakat mengalami peningkatan dalam hal konservasi mangrove serta peningkatan perekonomian. Kemudian kegiatan ini pula diharapkan mampu menjadi sebagai acuan bagi masyarakat yang lain yang masih acuh tak acuh terhadap ekosistem mangrove agar dapat mendorong kesadaran mereka agar melakukan konservasi mangrove.

\section{Kesimpulan}

Ekosistem mangrove di Desa Muladimeng, Kecamatan Ponrang, Kabupaten Luwu mempunyai peranan yang sangat penting baik dari segi fisik, ekologi maupun ekonomi. Ketergantungan masyarakat terhadap ekosistem mangrove sangat tinggi, utamanya dalam menopang kehidupan ekonominya. Tingginya ketergantungan tersebut menyebabkan tingkat eksploitasi mangrove semakin tinggi, akibatnya laju degradasi mangrove di kawasan ini semakin meningkat. Kondisi ini jika dibiarkan secara terus menerus akan berakibat semakin menurunnya kehidupan ekonomi masyarakat. Berbagai upaya konservasi mangrove telah dilakukan di kawasan ini, tetapi hasilnya kurang begitu optimal. Penilaian persepsi dan sikap masyarakat terhadap ekosistem mangrove akan memengaruhi dukungannya terhadap keberhasilan upaya konservasi mangrove. Penanaman pohon mangrove adalah salah satu usaha yang dapat dilakukan untuk mengurangi potensi abrasi pada daerah pesisir pantai. Dengan semakin tingginya kesadaran akan pentingnya hutan mangrove maka akan semakin tinggi tingkat pelestarian alam yang bisa dilakukan. Apabila seluruh lapisan masyarakat mempunyai komitmen yang tinggi dalam pelestarian pantai dan alamnya, maka akan semakin mudah kerjasama yang dapat dilakukan untuk memperbaiki daerah pesisir yang terdampak abrasi dan membantu perekonomian masyarakat sekitarnya. Kegiatan pengabdian ini dapat menstimulan perkembangan individu menjadi pribadi yang konstruktif. Menjadi lebih empatik, kooperatif, dan terbuka terhadap kritik dan saran yang membangun.

\section{Ucapan Terimakasih}

Terimakasi yang sebesar-besarnya kami ucapkan kepada seluruh pihak yang telah ikut andil dalam kegiatan ini terkhusus buat Ibu Camat Kecamatan Ponrang, Bapak Kapolsek Kecamatan Ponrang, Bapak Danramil Kecamatan Ponrang, Bapak Kepala Desa 
Muladimeng, Bapak Kepala Dusun dan Seluruh Masyarakat di Desa Muladimeng yang telah memberikan bantuan baik berupa materil maupun non materil

\section{Referensi}

Giri, C., Ochieng, E., Tieszen, L. L., Zhu, Z., Singh, A., Loveland, T., Masek, J. and Duke, N. (2011). Status and distribution of mangrove forests of the world using earth. Global Ecology and Biogeography, 20, 154-159.

Hewindawati, Y. T. (2018). Pengelolaan Ekosistem Mangrove Berbasis Masyarakat Secara Berkelanjutan: Studi Kasus Desa Blanakan, Subang, Jawa Barat. Seminar Nasional FMIPA Universitas Terbuka Peran Matematika, Sains dan Teknologi dalam Mencapai Tujuan Pembangunan Berkelanjutan/SDGs (pp. 305-27).

Hussain, S. A. and Badola, R. (2010). Valuing mangrove benefits: Contribution of mangrove forests to local livelihoods in Bhitarkanika Conservation Area, East Coast of India. Wetlands Ecology and Management, 18(3), 321-331.

Ledheng, L., \& Yustiningsih, M. (2018). Penanaman mangrove di perairan pantai Tanjung Bastian. Bakti Cendana, 1(1), 25-31.

Muharam, M. (2014). Penanaman Mangrive Sebagai Salah Satu Upaya Rehabilitasi Lahan dan Lingkungan di Kawasan Pesisir Pantai Utara Kabupaten Karawang.

Pontoh, 0. (2011). Peranan nelayan terhadap rehabilitasi ekosistem hutan bakau (mangrove). Jurnal Perikanan dan Kelautan Tropis, VII(2), 73-79

Rahmah, Y. (2014) Penanaman Pohon Mangrove di Desa Mangunharjo Tugu Semarang Sebagai Bentuk Kepedulian Lingkungan. Harmoni: Jurnal Pengabdian Kepada Masyarakat, 3(2), 1-5.

Setiawan, H., Purwanti, R., \& Garsetiasih, R. (2017). Persepsi dan sikap masyarakat terhadap konservasi ekosistem mangrove di Pulau Tanakeke Sulawesi Selatan. Jurnal Penelitian Sosial dan Ekonomi Kehutanan, 14(1), 57-70.

Uddin, M. S., de Ruyter van Steveninck, E., Stuip, M. and Shah, M. A. R. (2013). Economic valuation of provisioning and cultural services of a protected mangrove ecosystem: A case study on Sundarbans Reserve Forest, Bangladesh. Ecosystem Services, 5(October 2014), 88-93

Yuliasamaya, Darmawan, A. dan Hilmanto, R. (2014). Perubahan tutupan hutan mangrove di pesisir Kabupaten Lampung Timur. Jurnal Sylva Lestari, 2(3), 111-124. 